\title{
Upaya Pemerintahan Daerah dalam Penggunaan Inovasi Teknologi dalam Perencanaan Pembangunan Pemerintahan Daerah (Studi Kasus di Provinsi Sulawesi Selatan dan Provinsi Sumatera Barat)
}

\author{
Efforts of Local Governments in Using Technological Innovations in Local Government \\ Development Planning (Case Study in South Sulawesi Province and West Sumatra Province)
}

Siti Maemunah ${ }^{1 *}$, Adi Suhendra ${ }^{2}$

${ }^{1,2}$ Badan Penelitian dan Pengembangan, Kementerian Dalam Negeri RI

\begin{tabular}{l} 
ARTICLE INFO \\
\hline Article history: \\
DOI: \\
10.30595/pspfs.v1i.156 \\
Submitted: \\
July 9, 2021 \\
Accepted: \\
July 13, 2021 \\
Published: \\
Oct 31, 2021 \\
\hline
\end{tabular}

Keywords:

Planning Inovation, Region Development, Information System, Performance Assessment

\begin{abstract}
This technological development has become a medium used by a state administrator to improve the welfare or services of its citizens. An innovation to capture this phenomenon is needed. Local government innovation is very important in implementing good and reliable governance (Good Governance). The implementation of regional development always begins with research and development activities, as well as assessments. Development planning is not only done on the table, without seeing the reality on the ground. The core of the planning problem is making the plan itself which includes a series of procedures and involves many parties. The long process and the many parties involved often make planning ineffective. Based on this, this study aimed to compare the differences in planning innovations carried out in two different regions in South Sulawesi and West Sumatra to compare the innovations of the two regions. This study used a qualitative descriptive approach. As a result, South Sulawesi and West Sumatra had different development innovations. South Sulawesi emphasized improving a website-based information system that would be a reference for development planning. Meanwhile, West Sumatra emphasized assessing construction services that would carry out development planning in the West Sumatra region. Suggestions for the future, each agency allocated a budget to increase the capacity of the SIPPD admin management and provide cost consequences as motivation.
\end{abstract}

This work is licensed under a Creative Commons Attribution 4.0 International License.

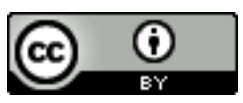

\section{Corresponding Author: \\ Siti Maemunah \\ Badan Penelitian Dan Pengembangan, Kementerian Dalam Negeri RI \\ Email: adisuhendra.jr@gmail.com}

\section{PENDAHULUAN}

Peningkatan kebutuhan dan pola hidup yang semakin kompleks, menuntut adanya suatu perkembangan yang menghasilkan kemudahan dalam setiap akses kebutuhan. Adanya perkembangan teknologi ini menjadi suatu media yang digunakan oleh suatu penyelenggara negara untuk meningkatkan kesejahteraan atau pelayanan bagi warga negaranya. Di perlukan suatu inovasi yang digunakan menangkap fenomena tersebut. Dalam hal ini pemerintah harus di hadapkan kepada suatu kondisi dimana harus memiliki ide-ide baru untuk dapat menyesuaikan dengan perkembangan dan fenomena yang ada (Nainggolan, 2019).

Penyelenggaraan pembangunan daerah selalu diawali aktivitas penelitian dan pengembangan. Studi yang dilakukan Kurniawansyah (2014) semakin mengukuhkannya. Kegiatan perencanaan pembangunan pada dasarnya merupakan kegiatan riset/penelitian, karena proses pelaksanaannya akan banyak menggunakan metode-metode riset, 
mulai dari teknik pengumpulan data, analisis data, hingga studi lapangan/kelayakan dalam rangka mendapatkan data-data akurat, baik yang dilakukan secara konseptual/dokumentasi maupun eksperimental.

Perencanaan pembangunan tidak hanya dilakukan di atas meja, tanpa melihat realita di lapagan. Hal tersebut sejalan dengan hasil studi Hidayat (2017) yang mengungkapkan bahwa perencanaan pembangunan daerah (PPD) akan membentuk 3 (tiga) hal pokok, yakni: a) perencanaan komunitas; b)menyangkut suatu area (daerah); dan c) sumber daya yang ada di dalamya. Dalam studi ini, perencanaan pembangunan diartikan sebagai proses yang rinci, runut, sekuen, terstruktur, sistematis, komprehensif, dan ilmiah untuk menyusun program/kegiatan sesuai tujuan yang tepat demi keberkelanjutan pembangunan suatu daerah dalam kurun waktu tertentu serta ditetapkan melalui kerangka regulasi/kebijakan. Secara operasional, perenanaan pembangunan daerah merupakan legitimasi penyaluran aspirasi masyarakat sekaligus penetapan kebijakan afirmatif demi terselenggaranya pembangunan secara inklusif di daerah. Hal ini penting untuk menentukan prioritas program/kegiatan, penetapan locus \& focus, perencana dan pelaku pembangunan, waktu pelaksanaan, dan pengalokasian anggaran pembangunan. Artinya, perencanaan pembangunan harus berpedoman pada arah kebijakan yang terukur, terencana, dan dilakukan oleh para pemangku kepentingan secara profesional dengan tolok ukur waktuyang telah ditentukan. Dalam konteks ini, perencanaan pembangunan mencakup pula kegiatan supervisi dan evaluasi terhadap seluruh aspek dan tahapan pembangunan beserta pengelolaan risikonya (risk management) secara komprehensif.

Faludi (1973) menyatakan dalam teori perencanaan ada dua pandangan yang membahas mengenai perencanaan yang baik. Pertama teori prencanaan rasional yang menyatakan bahwa perencanaan yang baik adalah perencanaan yang disusun berdasarkan akurasi data, hasil pengamatan (observasi yang mendalam) dan berdasarkan pengalaman atau hasil evaluasi yang diperoleh dari kasus sebelumnya. Kedua, teori perencanaan partisipatif/komunikatif yang menyatakan bahwa perencanaan yang baik adalah perencanaan yang melibatkan masyarakat dalam proses perencanaan. Pada prakteknya kedua teori tersebut telah dilaksanakan oleh pemerintah daerah dalam menyusun perencanaan pembangunan. Oleh karena itu, perencanaan seharusnya menghasilkan pencapaian pembangunan yang signifikan dan lebih baik dari tahun ke tahun.

Sedangkan teori prosedural (Theory of Planning) memandang perencanaan sebagai sebuah proses yang terkait dengan kapasitas perencana, operasionalisasi prosedur dalam penyusunan rencana dan kelembagaan yang bertanggung jawab menyusun dan menetapkan rencana. Berdasarkan pengertian tersebut maka apabila dipandang dari sudut teori prosedural maka inti masalah perencanaan adalah pada proses pembuatan rencana itu sendiri yang didalamnya terdapat serangkaian prosedur serta melibatkan banyak pihak. Proses yang panjang dan banyaknya pihak yang terlibat tersebut seringkali menyebabkan perencanaan menjadi tidak efektif (Ginting, 2016).

Berdasarkan hal tersebut, maka penelitian ini dimaksudkan untuk menganalisis perbedaan inovasi perencanaan yang dilakukan pada dua daerah yang berbeda yaitu di Sulawesi Selatan dan Sumatera Barat, untuk membandingkan inovasi kedua daerah tersebut.

\section{METODE PENELITIAN}

Kajian ini menggunakan pendekatan kualitatif-deskriptif. Data yang digunakan adalah data sekunder dari berbagai sumber. Penggunaan pendekatan berpikir sistem kualitatif digunakan untuk memahami kompleksitas sistem dan untuk mendukung proses berpikir intuitif-dialogis (Ismiatun, 2015).

Pada penelitian ini, fokus penelitian adalah inovasi dari sistem perencanaan yang dibuat oleh Pemerintah Provinsi Sulawesi Selatan dan Pemerintah Provinsi Sumatera Barat.

\section{HASIL DAN PEMBAHASAN}

\section{Sistem Informasi Perencanaan Pembangunan Daerah (SIPPD) di Provinsi Sulawesi Selatan}

Perencanaan pembangunan daerah adalah suatu proses penyusunan tahapantahapan kegiatan yang melibatkan berbagai unsur pemangku kepentingan di dalamnya, guna pemanfaatan dan pengalokasian sumber daya yang ada dalam rangka meningkatkan kesejahteraan sosial dalam suatu lingkungan daerah dalam jangka waktu tertentu (Jamal, 2019).

Perencanaan tidak lain dari susunan (rumusan) sistematik mengenai langkah (tindakan-tindakan) yang akan dilakukan di masa depan, dengan didasarkan pada pertimbangan-pertimbangan yang seksama atas potensi, faktorfaktor eksternal dan pihak-pihak yang berkepentingan dalam rangka mencapai suatu tujuan tertentu. Sedangkan, proses perencanaan merupakan sebuah proses yang dilakukan dalam rangka mencapai sebuah kestabilan, sehingga setiap aktivitas yang ada di dalamnya merupakan usaha yang dilakukan memiliki titik fokus untuk mencapai satu kondisi keseimbangan dalam konteks problem solving, future oriented dan resource allocation (Abe, 2001).

Salah satu inovasi yang dilakukan pemerintah Provinsi Sulawesi Selatan adalah pembuatan Sistem Informasi Perencanaan Pembangunan Daerah (SIPPD). Sistem Informasi Perencanaan Pembangunan Daerah (SIPPD) adalah merupakan sebuah sistem besar yang mendukung proses perencanaan pembangunan secara utuh, mulai dari proses perencanaan, pengendalian, dan evaluasi. Untuk itu, dalam proses pengembangan dan implementasinya perlu dilakukan secara bertahap sesuai kemampuan dan kondisi yang ada (Jamal, 2019). 
Sistem Perencanaan Pembangunan Nasional berdasarkan Undang-Undang Nomor 25 Tahun 2004 adalah satu kesatuan tata cara perencanaan pembangunan untuk menghasilkan rencana rencana pembangunan dalam jangka panjang, jangka menengah, dan tahunan yang dilaksanakan oleh unsur penyelenggara negara dan masyarakat di tingkat pusat dan daerah.

Terkait dengan proses perencanaan, maka daerah diwajibkan untuk menyusun Rencana Pembangunan Jangka Panjang Daerah (RPJPD) yang berjangka waktu 20 (dua puluh) tahun. RPJPD tersebut memuat tentang visi, misi serta arah pembangunan daerah. Selanjutnya dari dokumen perencanaan jangka panjang tersebut dijabarkan ke dalam Rencana Pembangunan Jangka Menengah Daerah (RPJMD) yang berjangka waktu waktu 5 (lima) tahun. RPJMD tersebut memuat kebijakan keuangan daerah, strategi pembangunan daerah, kebijakan umum, program SKPD dan lintas SKPD, program kewilayahan yang disertai dengan rencana-rencana kerja dalam kerangka regulasi dan kerangka pendanaan yang bersifat indikatif. Selanjutnya RPJMD dijabarkan ke dalam Rencana Kerja Pemerintah Daerah (RKPD) untuk tiap tahunnya untuk kemudian diimplementasikan ke dalam dokumen teknis Anggaran Pendapatan dan Belanja Daerah (APBD).

Undang-Undang Nomor 25 Tahun 2004 juga menyatakan bahwa Perencanaan adalah suatu proses untuk menentukan tindakan masa depan yang tepat, melalui urutan pilihan, dengan memperhitungkan sumber daya yang tersedia, dan menetapkan bahwa Sistem Perencanaan Pembangunan memiliki tujuan yaitu untuk mendukung koordinasi antar pelaku pembangunan; menjamin terciptanya integrasi, sinkronisasi, dan sinergi baik antardaerah, antarruang, antarwaktu, antar fungsi pemerintah maupun antara pusat dan daerah; Menjamin keterkaitan dan konsistensi antara perencanaan, penganggaran, pelaksanaan \& pengawasan; Mengoptimalkan partisipasi masyarakat; dan Menjamin tercapainya penggunaan sumberdaya secara efisien, berkeadilan \& berkelanjutan.

Oleh karena itu menjadi hal yang krusial bagi daerah untuk dapat melakukan integrasi dan sinergi proses perencanaan program \& kegiatan serta anggaran, mulai dari proses, MUSRENBANG, Penyusunan RKPD, Penyusunan RENJA-SKPD hingga KUA-PPAS, yang secara bersamaan menjaga konsistensi terhadap prioritas dan target kinerja tahunan maupun 5 tahunan yang telah ditetapkan di dalam RPJMD. Untuk itu Badan Perencanaan Pembangunan Daerah Provinsi Sulawesi Selatan mempersembahkan sebuah Inovasi dalam Perencanaan Pembangunan yaitu Aplikasi Sistem Informasi Perencanaan Pembangunan Daerah (SIPPD).

Tujuan dari diadakannya inovasi sistem informasi perencanaan pembangunan daerah di Sulawesi selatan ini adalah untuk menyingkronkan Program dan Kegiatan dalam dokumen perencanaan dimulai dari RPJMD, Renstra OPD, RKPD, Renja OPD; Menyediakan alat bantu bagi daerah (Propinsi dan kabupaten/kota) utamanya BAPPEDA dalam menyusun RPJMD, RKPD yang efisien dan efektif serta memastikan konsistensi OPD dalam penyusunan Program dan Kegiatan; Menyediakan alat bantu bagi kabupaten/kota dalam mengkompilasi usulan kegiatan pada menu MUSRENBANG, serta mengarahkan usulan tersebut pada masing-masing OPD yang sesuai dengan bidang kewenangannya; Menyediakan alat bantu penyusunan RENJA-SKPD, RKPD dan KUA-PPAS di BAPPEDA yang merupakan akumulasi dari seluruh RENJA-SKPD yang ada; Menciptakan sistem perencanaan yang efektif, efisien dan konsisten.

Kata kunci diatas adalah konsistensi, konsistensi Perencanaan mutlak diterapkan, banyangkan saja jika Penyusunan Dokumen Perencanaan disusun secara manual by paper atau diinput manual setiap tahun maka bisa saja OPD membuat program baru yang mana program tersebut tidak ada didalam RPJMD, hal itu sangatlah fatal. Dapat dijelaskan sub menu pada Aplikasi ini adalah :

1. SIM RPJMD, memuat Visi, Misi, Tujuan dan Sasaran, Indikator Sasaran; Arah Kebijakan; Program RPJMD; Renstra OPD (Program dan Kegiatan)

2. SIM RKPD yang memuat Rancangan Renja OPD/Rancangan RKPD; Musrenbang; Renja Final/RKPD Final

3. KUA/PPAS (Kebijakan Umum Anggaran/Prioritas Anggaran Sementara)

4. SIM MONEV, yang memuat Realiasasi Keuangan OPD; Evaluasi Kinerja OPD pada Dokumen Renja OPD; Evaluasi Kinerja Pemda pada Dokumen RKPD

Penjelasan mengapa inovasi ini tergolong kreatif dan innovative adalah karena Bappeda mengimport Data RPJMD, Visi, Misi, Tujuan, Sasaran dan Indikator Sasaran dan utamanya Program dan Outcome RPJMD kedalam SIM RPJMD OPD menjabarkan (melakukan penginputan) Program tersebut menjadi Kegiatan dan outputnya menjadi Renstra OPD.

Kemudian pada SIM RKPD, Pada awal tahun perencanaan, Program dan Outcome dan Kegiatan Renstra OPD pada tahun $n+1$ otomatis ditarik dari sub menu Renstra OPD, jadi OPD tidak perlu menginput kembali karena Sub Menu Renstra dan Sub Menu Renja OPD sudah terkoneksi. Laporan pada SIM RKPD yaitu Bab V RKPD (Indikasi Program dan Kegiatan) dan Bab III Renja OPD (Tujuan, Sasaran, Program dan Kegiatan)

Masih pada SIM RKPD, terdapat Sub Menu Musrenbang, pada menu ini Bappeda Kab/Kota diberikan akses untuk dapat mengusulkan usulan kegiatan untuk dilaksanakan didaerahnya. Usulan tersebut dihadapkan dengan kegiatan sesuai dengan Renstra OPD jadi tidak dimungkinkan menambah kegiatan baru jika kegiatan tersebut tidak urgent. 
Selanjutnya, SIM MONEV, pada Menu ini Program dan Kegiatan pada SIM RKPD otomatis ditarik masuk kedalam SIMONEV, SIMONEV adalah melakukan evaluasi terhadap capaian pada Dokumen Perencanaan utamanya Outcome dari Program dan Output dari Kegiatan serta realialisasi dari fisik dan keuangan OPD. Hal ini penting karena Perencanaan dan Pengendalian Evaluasi adalah suatu kesatuan, tidak bisa dipisah atau diparsialkan.

Dari penjelasan tersebut dapat diketahui bahwa SIPPD ada suatu kesatuan dalam menjalankan perencanaan pembangunan secara terstruktur, mekanismenya diawali dari Hulu (RPJMD) hingga ke Hilir (Monitoring dan Evaluasi), hal inilah yang menurut kami sangat innovatif dan kreatif.

Dalam hal pengusulan, SIPPD ini diusulkan oleh seluruh stake holder Perencanaan pada OPD, Kasubag Program berserta jajarannya mengharapkan sebuah inovasi dalam penyusunan perencanaan, para Subag Program dan staf mereka menginginkan bahwa Aplikasi yang sudah ada harus dikembangkan dan dipermudah dalam menjalankannya. Untuk itu Bidang Perencanaan Makro dan Pembiayaan Pembangunan, BAPPEDA Prov. Sulsel melakukan desain ulang terhadap SIMBANGDA yang menurut kami memang terlau parsial dan kurang user friendly. Hasilnya kami harus bekerja ekstra keras bagaimana cara menuangkan alur perencanaan hari Hulu menuju ke Hilir, dari RPJMD, Renstra OPD, RKPD, dan Renja PD menjadi satu kesatuan dalam Aplikasi SIPPD.

Pemecahan masalah dari SIPPD adalah membuat penyusunan Dokumen Perencanaan berjalan tepat waktu dan menghemat waktu. Bayangkan saja bahwa dokumen perencanaan utamanya Bab Program dan Kegiatan yang biasanya dikerjakan selama berbulan bulan, dapat dihemat waktunya hanya dalam hitungan minggu.

Ketidaktepatan waktu penyelesaian proses dalam aplikasi oleh pengguna yang mengarah pada inefisiensi, pengisian aplikasi yang seolah-olah berbelit-belit, masih adanya tidak konsistensi data dokumen yang ada sehingga memperlambat pengolahan data, kurangnya informasi terkait sistem aplikasi yang disajikan yang menyebabkan pengguna agak bingung dalam proses penginputan serta tampilan atau fitur yang terkesan masih konvensional.

Aplikasi SIPPD dapat di akses pada url sippd.sulselprov.go.id adapun hasil (output) dari aplikasi ini yaitu: 1. Konsistensi dari Program RPJMD ke Renstra OPD, Renstra OPD ke Renja OPD serta Monitoring dan Evaluasinya; 2. Aplikasi berbasis web, penggunaan aplikasi yang mudah dimengerti; 3. Konsistensi target dan outcome Program serta target dan output kegiatan, hal ini penting guna memastikan Visi dan Misi Gubernur dijabarkan secara tepat sasaran oleh OPD; 4. Efesiensi waktu dalam penyusunan Dokumen Perencanaan; 5. Mendukung pelaksanaan egovernment.

Perencanaan pembangunan yang sudah menggunakan sistem ini perlu dipelihara dan berkelanjutan agar setiap tahapan perencanaan pembangunan dapat dilakukan dengan baik, penggunaan SIPPD yang terkoneksi dan terintegrasi sangat memudahkan aparatur perencana dan pihak BAPPEDA dalam menyusun berbagai dokumen perencanaan pembangunan, jika memungkinkan perlu dilakukan pengembangan sistem sesuai dengan kebutuhan dan .regulasi agar pihak perencana dapat melaksanakan tugasnya dengan baik, menjaga konsistensi antar dokumen serta sesuai dengan regulasi dan dapat mengatasi berbagai kendala yang dihadapi (Jamal, 2019).

\section{Inovasi dengan Penilaian Kinerja Penyedia Jasa Konstruksi Perencanaan dan Pembangunan di Provinsi Sumatera Barat}

Perancangan dan perencanaan (planning and design) merupakan tahap awal yang berpengaruh sangat besar dan signifikan terhadap suksesnya suatu proyek, karena sebagian besar keputusan strategi dan pembiayaan proyek bergantung pada perencanaan proyek Konsultan perencana mempunyai peran dalam pengambilan keputusan dan sebagai translator dari kebutuhan pemilik dan arahan bagi pelaksana. Ide dan gagasan dari pemilik dituangkan dalam suatu dokumen perencanaan yang terdiri dari spesifikasi dan gambar untuk dilaksanakan oleh kontraktor. Kinerja konsultan perencana dapat diukur dari beberapa faktor yang ditinjau dari segi pembuatan dokumen, waktu, biaya dan kerangka acuan kerja (Wala, 2013).

Sejumlah kriteria yang paling berpengaruh disesuaikan dengan Undang Undang No.18 Tahun 1999 tentang Jasa Konstruksi (Pasal 1 ayat 4) dan Peraturan Presiden RI No. 54 Tahun 2010 tentang Pedoman Pelaksanaan Pengadaan Barang dan Jasa Pemerintah (Pasal 1 ayat 16 dan 17). Kinerja menjadi salah satu faktor yang terpenting yang bisa saja dapat menyebabkan kegagalan dari suatu proyek konstruksi. Hal ini karena kinerja diandaikan sebagai bahan bakar yang dibutuhkan untuk menjalankan sebuah mesin. Kegagalan suatu proyek bisa saja diakibatkan karena kinerja perencana yang kurang baik dalam komunikasi dan koordinasi. Kelalaian kinerja dapat menjadi penyebab error dalam proyek konstruksi. Kompleksnya proyek serta banyaknya pihak yang terlibat didalamnya menuntut adanya suatu kinerja yang efektif antar pihak.

Sehingga, penilaian kinerja sangat penting dalam mewujudkan pembagunan yang sesuai dengan tujuan. Penilaian kinerja adalah penilaian atas pelaksanaan pekerjaan yang dilaksanakan oleh penyedia jasa konstruksi, baik secara kualitas dan kuantitas berdasarkan kriteria atau indikator tertentu (Peraturan Bupati Kulon Progo, 2014).

Fungsi penilaian kinerja penyedia jasa konstruksi adalah untuk meningkatkan pemahaman dan kesadaran terhadap kewajiban pemenuhan tertib penyelenggaraan konstruksi, meningkatkan pemenuhan kualitas hasil pekerjaan konstruksi, dan meningkatkan kompetensi para pelaku jasa konstruksi. 
Hasil penilaian kinerja penyedia jasa konstruksi digunakan Tim Pembina Jasa Konstruksi sebagai bahan dalam pembinaan jasa konstruksi. Dan juga bisa menjadi salah satu acuan bagi SKPD dalam pengadaan barang/jasa yang dilaksanakan dengan pengadaan langsung atau penunjukan langsung.

Bidang Jasa Konstruksi merupakan bidang yang utama dalam melaksanakan agenda pebangunan nasional. Jasa Konstruksi sebagai salah satu bidang dalam sarana pembangunan, sudah sepatutnya diatur dan dilindungi secara hukum agar terjadi situasi

yang objektif dan kondusif dalam pelaksanaannya. Salah satu referensi hukum yang mengatur tentang jasa konstruksi adalah Undang-undang no. 2 Tahun 2017 tentang Jasa Konstruksi. Jasa Konstruksi adalah layanan jasa konsultasi perencanaan pekerjaan konstruksi, layanan jasa pelaksanaan pekerjaan konstruksi, dan layanan jasa konsultasi pengawasan pekerjaan konstruksi. Para pihak dalam suatu pekerjaan konstruksi terdiri dari pengguna jasa dan penyedia jasa. Pengguna jasa dan penyedia jasa dapat merupakan orang perseorangan atau badan usaha baik yang berbentuk badan hukum maupun yang bukan berbentuk badan hukum.

Dinas Pengelolaan Sumber Daya Air Provinsi Sumatera Barat merupakan salah satu instansi teknis selaku pengguna jasa di bidang jasa konstruksi. Sedangkan penyedia jasa merupakan pemenang lelang/seleksi/penunjukan langsung berdasarkan hasil evaluasi yang dilaksanakan oleh Unit Layanan Pengadaan (ULP) Sekretariat Daerah Provinsi Sumatera Barat.

Konstruksi yang baik sangat bergantung terhadap kinerja dari penyelenggaranya, terutama dari penyedia jasa. Untuk mengetahui kinerja penyedia jasa, maka perlu dilakukan penilaian terhadap kinerja mereka. Hal inilah yang melatarbelakangi Dinas PSDA Provinsi Sumatera Barat melakukan penilaian kinerja dari Penyedia Jasa khususnya yang melaksanakan kegiatan-kegiatan pada Dinas PSDA Provinsi Sumatera Barat.

Tujuan utama dari penilaian kinerja penyedia jasa untuk mengetahui kinerja dari masing-masing penyedia jasa pada pekerjaan konstruksi yang bekerja di Dinas PSDA Provinsi Sumatera Barat. Maka tujuan khususnya adalah 1. Menilai kinerja dari personil yang disediakan oleh penyedia jasa pekerjaan konstruksi yang bekerja di lapangan; 2. Menilai kinerja dari peralatan yang disediakan oleh penyedia jasa pekerjaan konstruksi di lapangan; 3. Menilai ketepatan waktu dari penyedia jasa pekerjaan konstruksi dalam penyelesaikan pekerjaan dimaksud; 4 . Menilai kinerja dari personil yang disediakan oleh penyedia jasa pekerjaan supervisi yang mengawasi pekerjaan di lapangan; 5. Menilai kinerja dari peralatan yang disediakan oleh penyedia jasa pekerjaan supervisi di lapangan; 6. Menilai ketersediaan personil inti seperti yang tertuang dalam dokumen kontrak terhadap pekerjaan supervise.

Manfaatnya adalah nilai kinerja dari penyedia jasa diharapkan dapat menjadi pedoman bagi Pemerintah Provinsi Sumatera Barat untuk mengetahui profesionalitas dari Penyedia Jasa di Provinsi Sumatera Barat umumnya dan Dinas PSDA Provinsi Sumatera Barat dan kedepannya diharapkan menjadi salah satu acuan dalam menentukan pemenang lelang/seleksi pada kegiatan konstruksi berikutnya.

Penilaian kinerja lingkungan mempunyai 2 aspek utama, yaitu penilaian kinerja proyek dan peringkat kinerja terhadap benchmarks. Dengan kata lain, alat penilaian (assessment tools) menyediakan kerangka kerja untuk mengumpulkan data tentang kinerja aktual proyek pada keseluruhan jumlah indikator yang dipilih dan alat peringkat (rating tools) menggunakan data tersebut untuk memberikan rating yang dapat digunakan untuk membandingkannya dengan benchmarks dan target internal (Newman et al, 2014). Dan hasil dari inovasi penilaian tersebut adalah tersedianya dokumen kinerja dari masing-masing penyedia jasa pekerjaan konstruksi di lingkungan Dinas PSDA Provinsi Sumatera Barat.

\section{Penyusunan Aplikasi pada Pemerintahan Daerah}

Secara umum gambaran Aplikasi Web menurut Wikepedia suatu aplikasi yang diakses menggunakan penjelajah web melalui suatu jaringan seperti Internet. Ia juga merupakan suatu aplikasi perangkat lunak komputer yang dikodekan dalam bahasa yang didukung penjelajah web (seperti Laravel, ASP, Perl, Java, Java Script, PHP, Python, Ruby, dll) dan bergantung pada penjelajah tersebut untuk menampilkan aplikasi.

Aplikasi web menjadi populer karena kemudahan tersedianya aplikasi klien untuk mengaksesnya, penjelajah web, yang kadang disebut sebagai suatu thin client (klien tipis). Kemampuan untuk memperbarui dan memelihara aplikasi web tanpa harus mendistribusikan dan menginstalasi perangkat lunak pada kemungkinan ribuan komputer klien merupakan alasan kunci popularitasnya.

Banyak keuntungan yang diberikan oleh Aplikasi berbasis Web daripada aplikasi berbasis desktop, sehingga aplikasi berbasis web telah diadopsi oleh perusahaan sebagai bagian dari strategi teknologi informasinya, karena beberapa alasan :

1. Akses informasi mudah,

2. Setup server lebih mudah

3. Informasi mudah didistribusikan

4. Bebas platform, informasi dapat disajikan oleh browser web pada sistem operasi mana saja karena adanya standar dokumen berbagai tipe data dapat disajikan 
Penyusunan database aplikasi pada pemerintahan daerah pada dasarnya menggunakan MySQL. MY SQL adalah sebuah perangkat lunak sistem manajemen basis data SQL (bahasa Inggris: database management system) atau DBMS yang multialur, multipengguna, dengan sekitar 6 juta instalasi di seluruh dunia. MySQL AB membuat MySQL tersedia sebagai perangkat lunak gratis di bawah lisensi GNU General Public License (GPL).

MySQL adalah sebuah implementasi dari sistem manajemen basis data relasional (RDBMS) yang didistribusikan secara gratis di bawah lisensi GPL (General Public License). Setiap pengguna dapat secara bebas menggunakan MySQL, namun dengan batasan perangkat lunak tersebut tidak boleh dijadikan produk turunan yang bersifat komersial. MySQL sebenarnya merupakan turunan salah satu konsep utama dalam basisdata yang telah ada sebelumnya; SQL (Structured Query Language). SQL adalah sebuah konsep pengoperasian basisdata, terutama untuk pemilihan atau seleksi dan pemasukan data, yang memungkinkan pengoperasian data dikerjakan dengan mudah secara otomatis.

Kehandalan suatu sistem basisdata (DBMS) dapat diketahui dari cara kerja pengoptimasi-nya dalam melakukan proses perintah-perintah SQL yang dibuat oleh pengguna maupun program-program aplikasi yang memanfaatkannya. Sebagai peladen basis data, MySQL mendukung operasi basisdata transaksional maupun operasi basisdata nontransaksional. Pada modus operasi non-transaksional, MySQL dapat dikatakan unggul dalam hal unjuk kerja dibandingkan perangkat lunak peladen basisdata kompetitor lainnya.

Hal paling mendasar yang menjadikan MySQL pilihan utama sebagai database yang digunakan adalah karena MySQL menggunakan Lisensi GPL dan multiplatform, sehingga lebih disukai para mahasiswa karena tidak membutuhkan biaya besar dalam membuat aplikasi serta tidak harus tergantung pada OS Windows ataupun Linux karena dapat dijalankan pada kedua OS tersebut dan beberapa OS lainnya. Tapi alasan tersebut tidaklah cukup untuk menjadikan MySQL sebagai RDBMS yang akan digunakan. Berikut keunggulan lain yang diberikan adalah sebagai berikut:

1. Berlisensi GPL dan Multi Platform.Dapat diintegrasikan dengan beberapa bahasa Pemrograman seperti .Net, Java, Python, Perl yang merupakan bahasa pemrograman yang paling dominan di kalangan programmer.

2. Mendukung ODBC untuk sistem operasi Windows sehingga bisa digunakan aplikasi yang berjalan diwindows.

3. Bisa dijalankan pada spesifikasi hardware yang rendah karena lebih hemat resource memory (dibandingkan database lain) sehingga mudah digunakan untuk bahan pembelajaran.

4. MySQL dapat mendeteksi pesan kesalahan pada klien dengan menggunakan lebih dari 20 bahasa meskipun bahasa indonesia belum termasuk didalamnya.

5. MySQL dapat diintegrasikan dengan Hosting.

Secara umum PHP MY ADMIN digunakan untuk untuk mengelola database MySQL dan database MariaDB dengan lebih mudah melalui antarmuka (interface) grafis. Aplikasi web ini ditulis menggunakan bahasa pemrograman PHP. Sebagaimana aplikasi-aplikasi lain untuk lingkungan web (aplikasi yang dibuka atau dijalankan menggunakan browser), phpMyAdmin juga mengandung unsur HTML/XHTML, CSS dan juga kode JavaScript. Aplikasi web ini ditujukan untuk memudahkan pengelolaan basis data MySQL dengan penyajian antarmuka web yang lengkap dan menarik.

phpMyAdmin menawarkan fitur yang mencangkup pengelolaan keseluruhan server MySQL (memerlukan superuser) dan basis data tunggal. phpMyAdmin juga mempunyai sistem internal untuk mengelola metadata dan mendukung fitur-fitur untuk operasi tingkat lanjut. Melalui sistem administrator, phpMyAdmin juga dapat mengelola users dan sekaligus hak aksesnya (privilage).

Adapun metode yang digunakakan dalam pembuatan aplikasi ini adalah dengan menggunakan pendekatan SDLC (Metode waterfall) SDLC merupakan metode yang sering digunakan oleh penganalisa sistem pada umumnya. Inti dari metodewaterfall adalah pengerjaan dari suatu sistem dilakukan secara berurutan atau secara linear. Jadi jika langkah ke-1 belum dikerjakan, maka langkah 2 tidak dapat dikerjakan. Jika langkah ke-2 belum dikerjakan maka langkah ke3 juga tidak dapat dikerjakan, begitu seterusnya. Secara otomatis langkah ke-3 akan bisa dilakukan jika langkah ke-1 dan ke-2 sudah dilakukan.

Keunggulan model pendekatan pengembangan software dengan metode waterfall adalah pencerminan kepraktisan rekayasa, yang membuat kualitas software tetap terjaga karena pengembangannya yang terstruktur dan terawasi. Disisi lain model ini merupakan jenis model yang bersifat dokumen lengkap, sehingga proses pemeliharaan dapatdilakukan dengan mudah. Akan tetapi dikarenakan dokumentasi yang lengkap dan sangat teknis, membuat pihak klien sulit membaca dokumen yang berujung pada sulitnya komunikasi antar pengembang dan klien. Dokumentasi kode program yang lengkap juga secara tak langsung menghapus ketergantungan pengembang terhadap pemrogram yang keluar dari tim pengembang. Hal ini sangat menguntungkan bagi pihak pengembang dikarenakan proses pengembangan perangkat lunak tetap dapat dilanjutkan tanpa bergantung pada pemrogram tertentu. 


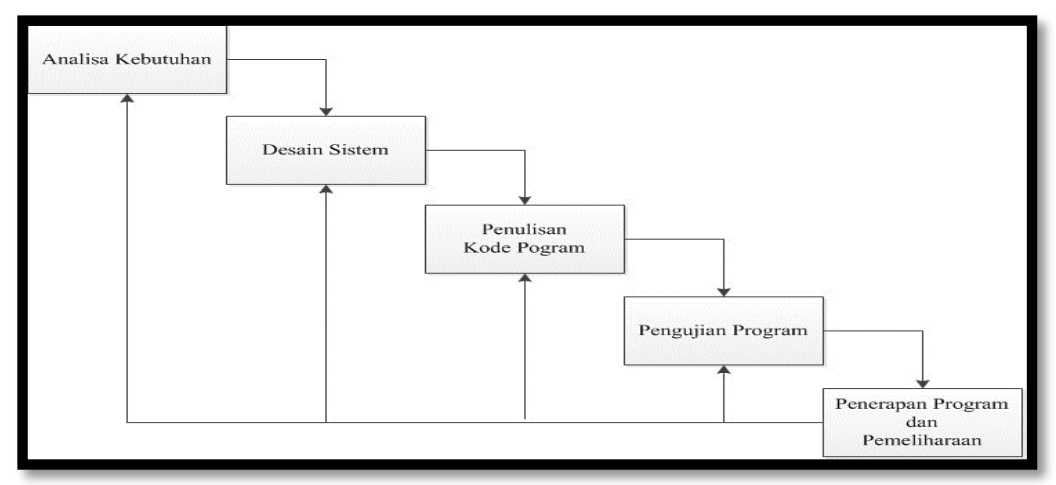

Gambar 1. tahapan metode waterfall

Secara garis besar metode waterfall mempunyai langkah-langkah sebagai berikut: Analisa, Desain, Penulisan, Pengujian dan Penerapan serta Pemeliharaan (Kadir, 2003). Adapun tahapan dalam penggunaan metode ini adalah sebagai berikut:

1. Analisa Kebutuhan

Langkah ini merupakan analisa terhadap kebutuhan sistem. Pengumpulan data dalam tahap ini bisa melakukan sebuah penelitian, wawancara atau studi literatur. Sistem analis akan menggali informasi sebanyak-banyaknya dariuser sehingga akan tercipta sebuah sistem komputer yang bisa melakukan tugas-tugas yang diinginkan oleh usertersebut. Tahapan ini akan menghasilkan dokumen user requirment atau bisa dikatakan sebagai data yang berhubungan dengan keinginan user dalam pembuatan sistem. Dokumen ini lah yang akan menjadi acuan sistem analis untuk menerjemahkan ke dalam bahasa pemrogram.

2. Desain Sistem

Tahapan dimana dilakukan penuangan pikiran dan perancangan sistem terhadap solusi dari permasalahan yang ada dengan menggunakan perangkat pemodelan sistem seperti diagram alir data (data flow diagram), diagram hubungan entitas (entity relationship diagram) serta struktur dan bahasan data.

3. Penulisan Kode Program

Penulisan kode program ataucoding merupakan penerjemahan design dalam bahasa yang bisa dikenali oleh komputer. Dilakukan oleh programmeryang akan meterjemahkan transaksi yang diminta oleh user. Tahapan ini lah yang merupakan tahapan secara nyata dalam mengerjakan suatu sistem. Dalam artian penggunaan komputer akan dimaksimalkan dalam tahapan ini. Setelah pengkodean selesai maka akan dilakukan testing terhadap sistem yang telah dibuat tadi. Tujuan testing adalah menemukan kesalahan-kesalahan terhadap sistem tersebut dan kemudian bisa diperbaiki.

4. Pengujian Program

Tahapan akhir dimana sistem yang baru diuji kemampuan dan keefektifannya sehingga didapatkan kekurangan dan kelemahan sistem yang kemudian dilakukan pengkajian ulang dan perbaikan terhadap aplikasi menjadi lebih baik dan sempurna.

5. Penerapan Program dan Pemeliharaan

Perangkat lunak yang sudah disampaikan kepada pelanggan pasti akan mengalami perubahan. Perubahan tersebut bisa karena mengalami kesalahan karena perangkat lunak harus menyesuaikan dengan lingkungan (periperal atau sistem operasi baru) baru, atau karena pelanggan membutuhkan perkembangan fungsional.

\section{KESIMPULAN}

Berdasarkan hasil studi literatur yang telah dilakukan, dapat ditarik kesimpulan sebagai berikut:

1. Untuk proyek low budget dan membutuhkan sensor untuk deteksi getaran pada 3 sumbu, maka dapat menggunakan sensor accelerometer ADXL330, ADXL335, ADXL345, MPU6050 maupun H48C. Namun untuk rekomendasi utama dari sensor 3-axial adalah ADXL345, Sementara apabila hanya membutuhkan sensor untuk deteksi getar, maka sensor SW-420 dapat menjadi pilihan.

2. Untuk proyek yang tidak memperhatikan harga sensor, maka sensor geophone, Omron D7S, dan Trillium 120P dapat menjadi pilihan. Ketiga sensor ini sangat direkomendasikan, keputusan pemilihan sensor dikembalikan pada kebutuhan proyek. Untuk proyek sedang, maka bisa menggunakan Omron D7S atau geophone untuk sensitivitas yang lebih tinggi. Seismometer Trillium 120P direkomendasikan untuk proyek yang lebih besar dengan kebutuhan akurasi deteksi gempa yang lebih tinggi. 


\section{UCAPAN TERIMA KASIH}

Peneliti mengucapkan terima kasih kepada informan dan juga Pemerintah Provinsi Sulawesi Selatan dan Sumatera Barat yang telah memberikan berbagai macam informasi dan data yang menunjang pembuatan penelitian yang luar biasa ini, tentang perbedaan inovasi perencanaan di Provinsi Sulawesi Selatan dan Sumatera Barat.

\section{DAFTAR PUSTAKA}

Abe, Alexander, 2001, Perencanaan Daerah Memperkuat Prakarsa Rakyat. Dalam Otonomi Daerah, Lappera Pustaka Utama, Yogyakarta.

Faludi, Andreas. 1973. Planning Theory. Pergamon Press. Britain.

Ginting, A., B. Supriyono., dan I. Noor. 2016. Perencanaan Pembangunan Daerah Dalam Rangka Meningkatkan Daya Saing (Studi Pada Provinsi Bengkulu). J. Wacana. 19 (1) : 56-65.

Hidayat R., Wahyu. 2017. Perencanaan Pembangunan Daerah : Pendekatan. Pertumbuhan Ekonomi, Disparitas Pendapatan, dan Kemiskinan di Jawa. Timur.

Ismiatun. 2015. Pengembangan Sistem Inovasi Dalam Perspektif Peningkatan Daya Saing Daerah Dengan Pendekatan System Dynamics. JISIP. 4(2) : 253-261.

Jamal, A.L., H. Anam., dan M.A. Djirimu. 2019. Kajian Tentang Fungsi Sistem Informasi Perencanaan Pembangunan Daerah (Sippd) Dalam Proses Perencanaan Pembangunan Di Kabupaten Poso. E-J. Katalogis. 4(1) : 60-67.

Kurniawansyah, Helmi. 2014. Peran Perencanaan Dalam Pembangunan Jalan Pada Dinas Bina Marga dan Pengairan Kota Samarinda. e-Journal Ilmu Pemerintahan. 2 (3)2605 -2615.

Nainggolan, R.D.N., dan T. Yuwono. 2019. Inovasi Pemerintah Daerah dalam Sistem Perencanaan Berbasis Teknologi Informasi untuk mewujudkan Good Governance di Kota Semarang. Departemen Politik dan Pemerintahan FISIP UNDIP. Semarang.

Newman, P., Hargroves, C., Desha, C., Kumar, A., Wilson, K., Farr, A., Whistler, L., dan Matan, A. 2014. A Literature Review of Sustainability Performance Assessment by Road Agencies for The Sustainable Built Environment National Research Centre. A Collaborative Project between Curtin University and Queensland University of Technology. Bentley, WA

Peraturan Bupati Kulon Progo. 2014. Berita Daerah Kabupaten Kulon Progo. Peraturan Bupati Kulon Progo Nomor 5 Tahun 2014 tentang Penilaian Kinerja Penyedia Jasa Konstruksi.

Wala, M. 2013. Penilaian Kinerja Konsultan Perencana Bangunan dengan Metode Analytic Hierarchy Process (Studi pada Perencana Bangunan di Manado). J. Ilmiah Media Engineering. 3 (2) : 99-108. 